\title{
Needs Assessment for a University-based Youth Clinic in Beirut, Lebanon: A Mixed Quantitative and Qualitative Study
}

\author{
Nancy Maroun*,1,2 ${ }^{\text {Hyam Kahi }}{ }^{2}$, Nathalie Chemaly ${ }^{2}$, Hala ElKahi ${ }^{2}$, and Elie A. Akl ${ }^{3}$ \\ ${ }^{1}$ Sociology Department, Buffalo State College, Buffalo, NY, USA \\ ${ }^{2}$ University Center for Family and Community Health, Saint Joseph University, Beirut, Lebanon \\ ${ }^{3}$ Department of Internal Medicine, American University of Beirut, Lebanon
}

\begin{abstract}
This study aims to evaluate the needs, interests, and barriers to using the services of a university-based Youth Clinic in an inner city area of Beirut-Lebanon. The population consisted of 12-22 year old students of schools and universities located in the targeted area, and of other stakeholders active in the targeted area. We conducted a survey of 629 school students; a survey of 295 first year university students; a focus group with parents and educators; and interviews with organizations. Results indicated that the preferred means of service delivery for school and university students was an Internet site for youth health. Their top topic of interest was diet and nutrition. Their preferred location for meeting the clinic's staff was the clinic itself. School students preferred being accompanied by friends, university students preferred being on their own. The top barrier for the students was the 'feelings of embarrassment and annoyance'. Parents, educators, and organizations representatives reported a lack of health related services and activities specialized for the youth. They expressed an urgent need for social and psychological support and for counseling services. Their top topics of interest were parents-youth relationship, sexual education, smoking, diet and nutrition. Their mostly discussed barrier was the services' cost. While students valued a health Internet site and were mostly interested in the topic of diet and nutrition, parents and educators expressed the need for social and psychological support and for counseling services. Youth Clinics should assess and tailor their services to the need of their local community.
\end{abstract}

Keywords: University-based youth clinic, Lebanon, Needs assessment, Qualitative study, Quantitative study.

\section{INTRODUCTION}

Youth have specific health related needs that require specialized services. While they typically perceive themselves as 'healthy', they may have significant health issues that are often ignored and/or under-diagnosed [1,2]. Indeed, risky behaviors such as use of illicit drugs, alcohol abuse, unsafe sexual behaviors, smoking [3], depression [4,5], and suicidal behaviors are prevalent in this age group $[5,6]$.

It is more challenging for younger people to recognize health issues and to seek help. Barriers include lower socioeconomic class [7], lack of medical insurance [8-11], concerns about confidentiality, embarrassment [8-10,12,13], lack of trust in health professionals, and unawareness of existing services $[9,10]$. As a result, they tend to bypass formal health structures and seek informal help when faced with health concerns $[7,9,13]$. They seek help not only from parents and friends, but also from the internet[14-16].

In a 1999 survey of high school students in Lebanon (mean age 17.5; SD 1.36), 15\% of respondents reported suicidal thoughts, $6 \%$ reported having a plan for suicide at one point of their life, and $5 \%$ reported a suicidal attempt at one point of their life [17]. In another survey, 37\% of high school students reported having at least one friend user of illegal drugs and $7 \%$ reported abusing alcohol. In the same

*Address correspondence to this author at the Sociology Department, Buffalo State College, Buffalo, NY, US; Tel: (716) 878-3913;

Fax: (716) 878-4009; E-mail: nancy.maroun@gmail.com survey, $42 \%$ of university students reported having at least one friend user of illegal drugs, 9\% reported consuming alcohol regularly, and 3\% reported consuming some psychoactive medications [18]. In a 2005 survey in 100 schools across Lebanon [19] 4 out of 10 students reported being physically hit by a family member, 1 out of 4 students reported being physically hit by a teacher, and 2 out of 10 students reported being sexually harassed in the preceding month. One out of 4 students reported not hearing about HIV or AIDS while 8 out of 10 students and 7 out of 10 students had not asked their teacher or their parents respectively about reproductive and sexual health topics.

Health interventions targeting youth have not been a health policy priority in Lebanon [20] and have been very limited [21]. To help fill this gap, the University Center for Family and Community Health (CUSFC) of Saint Joseph University (USJ) of Beirut established its Youth Clinic in January 2005, the first of its kind in Lebanon (see detailed information in Box I). The aim of this study was to evaluate the needs, interests, and barriers to using the services of a university-based Youth Clinic in an inner city area of Beirut.

\section{MATERIALS AND METHODOLOGY}

\section{Overall Project Design}

We conducted two quantitative studies: a survey of students of schools located in the clinic's neighborhoods and a survey of students of universities located in the clinic's neighborhoods. We chose a survey study design to quantify 
these two group's health service usage and preferences. We also conducted two qualitative studies: a focus-group with parents and educators of the schools' students and interviews with representatives of Non-Governmental Organizations (NGOs) active in the clinic's neighborhoods. We chose a qualitative study design to explore and understand parents, educators, and community worker's needs of, interests in, and barriers to access of health services.

Participants in the different studies received no monetary or non-monetary incentives. We implemented quality assurance measures such as training, and supervision of the research assistants and quality control measures such as verifying data collection and double-checking of data entry. The Saint Joseph University's ethical review committee reviewed the study. We present below the methodological details of each of the four studies.

\section{Quantitative Studies}

\section{Populations}

The targeted populations consisted of youth, defined for the purpose of this study as 12-22 years old individuals. The first target population consisted of students of the $8^{\text {th }}, 9^{\text {th }}$, $10^{\text {th }}, 11^{\text {th }}$, and $12^{\text {th }}$ grades in the 7 schools (3 public and 4 private) located in the geographical area of the Youth Clinic. The officials of one school declined allowing us to invite their students to participate in our study. We sampled all eligible students in five of the six schools agreeing to participate $(n=485)$. The $6^{\text {th }}$ and largest school (with multiple classrooms for each grade), we randomly selected one classroom per grade $(n=144)$.

The second target population consisted of first year students of university campuses located in the geographical area of the Youth Clinic. There were two eligible private universities, with a total of three campuses. We randomly chose one academic department from each campus and invited its students to participate $(\mathrm{n}=295)$.

\section{Questionnaire}

We developed the survey questionnaire and refined it based on input from five qualitative interviews with young individuals. Two independent researchers reviewed iterative versions of the questionnaire for face and content validity. We developed both a French and an Arabic versions of the questionnaire. The initial version was in French and we created the Arabic version through a translation and backtranslation process. We pilot tested the questionnaire in both languages with 13 young individuals to insure clarity and feasibility.

The questionnaire included a total of 34 questions covering: demographic characteristics, use of health services over the previous 12 months, interest in services offered by a youth clinic, interest in means of offering services, interest in youth health topics, preferred location and company for meeting a youth clinic personnel, and barriers to using a youth clinic. We also recorded the class level and the educational institution of each participant. Answers to questions about degrees of interest were on a five point Likert scale with the following five anchors: not interested at all, not in- terested, neutral, interested, very much interested. Participants had the option of providing narrative comments for a number of questions.

\section{Data Collection}

We conducted the survey in March and April 2009. The survey was anonymous and self-administered. We chose the language version of the questionnaire (Arabic vs. French) depending on the primary language of instruction at each educational institution.

\section{Data Analysis}

We recoded the answers to the 5-point scale into 3 categories: "interested", "neutral", and "not interested". We stratified all analyses by the category of educational institution (i.e., school vs. university). We conducted a descriptive analysis using mean and standard deviation for continuous variables, and frequencies and percentages for categorical variables. We entered and managed data in Microsoft Office Excel, and conducted the analysis using SPSS 16.0 (SPSS, Inc., Chicago, Illinois).

\section{Qualitative Studies}

\section{Populations}

For the one focus group we conducted, we used purposive sampling to recruit participants with a wide representation of schools and areas of the neighborhood. Participants included 6 parents of students in the neighborhoods' schools and 2 educators who teach in those schools. For the interviews, we recruited representatives of four health related NGOs located in the clinic neighborhoods, and in contact with teenagers and young people, or with their parents.

\section{Data Collection}

The principal investigator (NM) conducted the focus group and the semi-structured individual interviews in April 2009. She used a discussion guide that included procedural instructions as well as open-ended questions that provided a framework for the discussion. The focus-group aimed to allow participants to express their opinions with reference to the Youth Clinic in order to cover both parents and educators perspectives besides the students and NGOs. The questions focused on exploring the needs of, interests in, and barriers to access of health services as perceived by parents, educators, and community workers. The interviewer audiorecorded the discussions and took notes. The focus-group discussion lasted 1 hour 35 min. Each individual interview lasted about 1 hour 30 min.

\section{Data Analysis}

We transcribed verbatim and translated into English the focus group and interviews. The translation was sentencefor-sentence in an "attempt to preserve the cultural meanings and nuances of the original"[22]. The risk of losing cultural meanings through translation was minimized by frequently consulting the raw data. The principal investigator (NM) then analyzed the discussions using an inductive process (grounded theory) to determine emerging concepts. The inductive process of generating knowledge from data, a key element of this research, is a ground-up process that allows 
concerned people to express themselves and allows the researcher to infer theoretical and empirical significance from their words [23]. It allows exploring cultural themes, roles and behaviors within communities [24].

\section{RESULTS}

\section{Quantitative Studies}

Participants in the survey consisted of 629 school students and 295 university students (response rate: 100\% and 97\% respectively). Demographic characteristics, the medical history, and the distribution of participants by type of the educational institution are reported in Table $\mathbf{1}$. Table 2 reports the interests in Youth Clinic services, in means of service delivery, and in youth health topics. Table 3 reports the preferred location and company for meeting the Youth Clinic team, and the barriers to using the services of a Youth Clinic. Finally, Table 4 reports the preferences of students for receiving youth health information.

\section{Qualitative Studies}

The participants included 6 parents of students in the neighborhoods' schools, 2 educators who teach in those schools, and representatives of 4 NGOs operating in that neighborhood. The participants' overall level of interest in the Youth Clinic and its services was very high. We present here the three themes that emerged: services of interest, topics of interest, and barriers.

\section{Services of Interest}

The participants reported a need for three services: 1) social and psychological counseling, 2) Internet site for youth, and 3) community outreach. They also reported a list of suggestions outlined in box II.

\section{1) Social and Psychological Counseling}

The participants particularly appealed for psychological assistance for parents-youth relationships. They noted that while medical and nutrition information could be learned from TV programs or by reading books and magazines, psy- chological and social counseling require the support of a specialized professional. Educators also viewed the social and psychological counseling as a highly needed service, especially in schools lacking the appropriate staff (i.e., social workers, psychologists) to offer it.

"It is hard to deal with youth. They argue so much and we got to a point we are unable to argue with them anymore. We got tired and are not sure how to act. We got to a point where we need someone specialized capable of helping us" (a parent)

Participants specified two forms of counseling services that would respond to their needs: individual support in the form of one-on-one meeting with professionals; and group support in the form of group meetings or seminars for parents with professionals, once or twice per week.

\section{2) Internet Site for Youth}

Both parents and educators highly appreciated a specialized website and the possibility of getting in contact with professionals through it. Both parents and educators argued that youth may fear to speak or ask in a direct manner or in person, and "being able to send a question and get answered by email or through the website will encourage them". Also, the parents of the school students stated "it is comforting to trust the institution and the health service team who give information to our children". One parent had a different point of view claiming that children and youth are already spending too much time on the net and preferred individual contact.

\section{3) Community Outreach}

Participants outlined the necessity of having the Youth Clinic reach out to the community. They proposed a number of ideas on how to involve the youth and the whole community, along with NGOs and grassroots organizations. Their suggestions could be categorized in six points (Box III). Parents believed that such community outreach activities can play a huge role in drawing the youth away from the tense political atmosphere and bad acquaintances toward more beneficial activities.

Box I. Description of the Youth Clinic of the University Center for Family and Community Health (CUSFC) of Saint Joseph University (USJ) of Beirut

The Youth Clinic (http://www.cusfc.usj.edu.lb/files/jeunes.htm) provides health services targeting teenagers and young people, as well as their parents. These services include medical, psychological, dietetic, social, nursing, and other types of consultations as needed. The Youth Clinic team is multidisciplinary and includes family physicians, psychologists, dietitians, social workers, nurses, physiotherapists, and lawyers. The services are provided either in one-on-one contacts or as group activities. While some services are provided by an individual professional others are provided in an interdisciplinary approach. The Youth Clinic also attempts to integrate health promotion and disease prevention.

Since establishing the center, a number of evaluations showed the necessity for adapted methods to reach the targeted population. One of the adapted methods was the launching in March 2008 of a French language youth friendly website (www.infosantejeunes.usj.edu.lb). The main objectives of the website were to: 1) inform adolescents and young between 12 and 22 years old on topics related to their health and safety; 2) provide them with the opportunity to anonymously ask questions and receive answers from the health team in a timely manner; and 3) support parents and care givers on issues related to their youth' health. The website covers topics such as nutrition, the human body, health care, vaccinations, stress, accident prevention, sexuality, and travel safety. The website was first developed in French and is now being translated into Arabic through the financial support of the United Nations Population Fund (UNFPA). 
Table 1. Comparison of the Demographic, Medical History, and Type of Educational Institution of High School Students and University Students Participating in the Survey

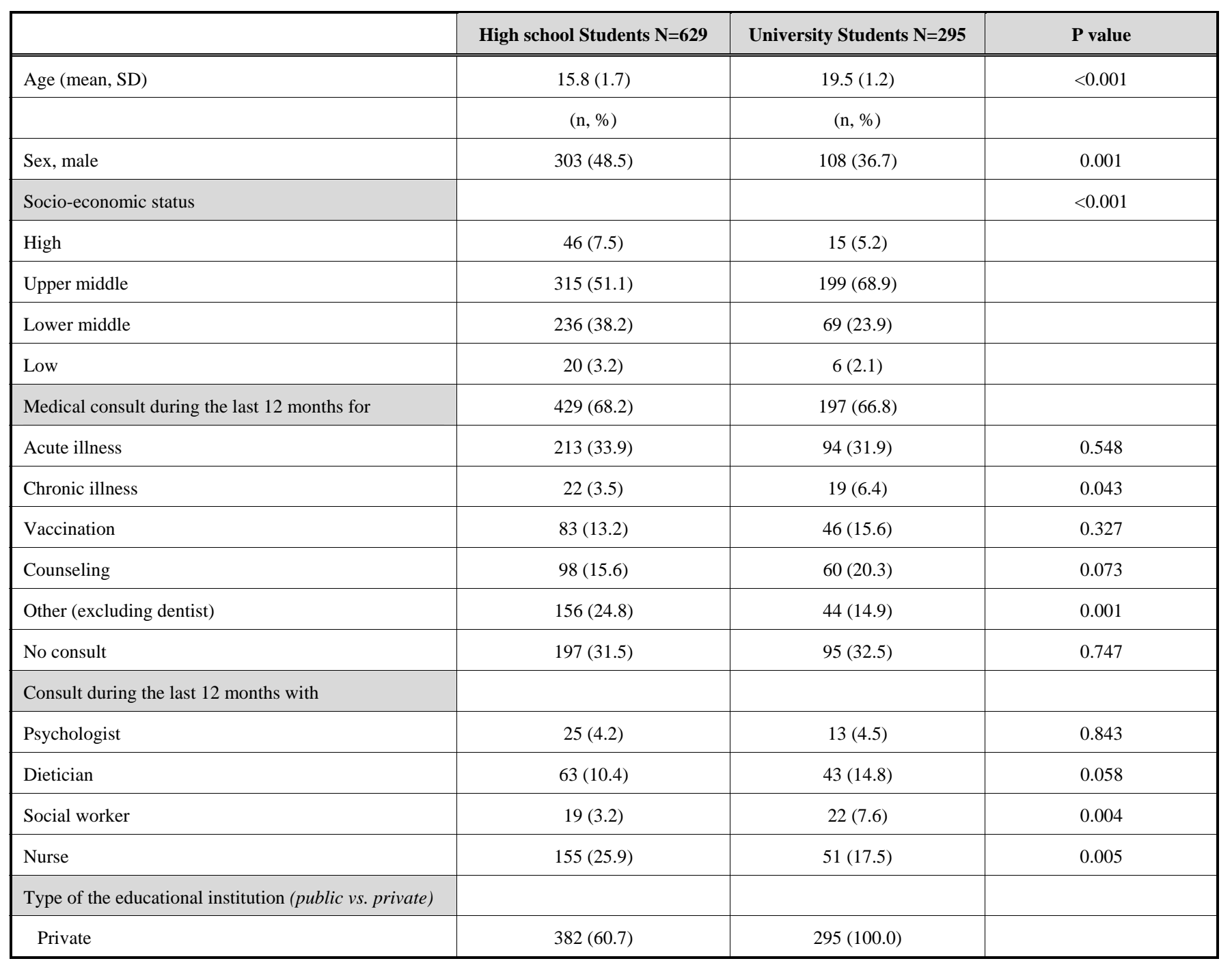

\section{Box II}

\section{Suggestions by parents, educators, and NGO representatives}

The participants had a number of suggestions to encourage youth to use the Youth Clinic:

- $\quad$ Link the idea of youth services with learning new information, and not with youth problems.

- Approach youth through activities and events that would interest and attract them, and not only through medical consultation.

- Make the Youth Clinic and its health service team easily accessible to students.

- $\quad$ Establish a family membership card for the Youth Clinic.

- $\quad$ Increase the age limit up to 30 years old instead of 22.

- $\quad$ Enlarge the geographic coverage of the center.

- $\quad$ Break the ice between health agents and the youth through entertaining activities

\section{Topics of Interest}

Participants focused on five topics: 1) Relationships between the youth and their parents: a high demand topic; 2) Sexual education: educators argued that youth would not discuss with their parents. Parents and educators regarded the Youth Clinic as a resource for the youth the parents can trust; 3) Drugs; 4) Active and passive smoking, and the role of peer pressure in the initiation of the smoking habit, including waterpipe (also known as hookah) smoking; and 5) Diet and nutrition: highly suggested by educator, especially for young girls, yet less of interest for parents arguing that such information could be retrieved from magazines, TV, and radio programs. 
Table 2. Comparison of High School Students and University Students for their Health Related Interests*

\begin{tabular}{|c|c|c|c|}
\hline & High School Students N=629 & University Students N=295 & $P$ value \\
\hline Medical consultations & $323(52.0)$ & 169 (57.9) & 0.171 \\
\hline Dietetic consultations & $330(53.7)$ & $155(53.3)$ & 0.496 \\
\hline Social worker assistance & $241(39.1)$ & $96(33.4)$ & 0.033 \\
\hline Nursing care & $277(45.3)$ & 135 (45.9) & 0.477 \\
\hline Internet site for youth & $383(61.9)$ & $136(46.4)$ & $<0.001$ \\
\hline Health information & $438(70.8)$ & $202(68.7)$ & 0.684 \\
\hline Individual meeting with specialist & $261(41.8)$ & $123(42.3)$ & 0.135 \\
\hline Group meeting with specialist & $280(44.9)$ & $121(41.4)$ & 0.203 \\
\hline Hotline with specialist & $154(24.7)$ & 65 (22.3) & 0.058 \\
\hline Site Internet for youth health & $372(59.3)$ & $136(46.4)$ & 0.001 \\
\hline email communication with specialist & $275(43.8)$ & 93 (31.7) & $<0.001$ \\
\hline \multicolumn{4}{|l|}{ Interest in youth health topics } \\
\hline Diet and weight & $461(73.5)$ & $199(68.6)$ & 0.220 \\
\hline
\end{tabular}

* Data for 'neutral' and 'not interested' are not provided in this table

\section{Barriers}

Participants outlined four main barriers that would prevent the youth from using a Youth Clinic: 1) Cost of services; students would be dependent on their parents in the form of insurance coverage or direct financial support. NGO representatives noted that the families are usually willing to pay for urgent care services, but not preventive services; 2) Youth feelings of fear, embarrassment, and discomfort; 3) Being used to consulting a primary care physician: "people are not used to consult a primary care center when they have a headache. NGOs consult a specialist”; 4) Location of the clinic in a neighborhood dominated by a different religious community. Individual and families from one religious community may not be willing to use the health services of a clinic located in a neighborhood dominated by the other religious community, and/or affiliated with political movement that is different from theirs. This was less of a concern for the university-based youth clinic given its location at the juncture of neighborhoods of different religious community.
In addition, the parents agreed that the clinic is trustful and respected particularly because of its university affiliation. One parent stated that the "university did not undergo recently any political and confessional violent events among youth”; and 5) Schedule of services: NGO representative pointed that it would be easier for young people to make evenings and weekend's appointments.

\section{DISCUSSION}

In summary, the youth responding to our survey reported interest in the following health services: medical consultations, dietetic consultations, and medical information services. Their mostly preferred mean to address health issues was an Internet site for youth health. The top two topics of interest were diet and nutrition, and body changes. The top preferred location for meeting the clinic's team was the clinic itself. More school students preferred meeting with clinic team accompanied by friends while more university students preferred meeting with health team on their own. The major 
Table 3. Comparison of High School Students and University Students for their Preferences and Perceived Barriers to using the Services of the Youth Clinic

\begin{tabular}{|c|c|c|c|}
\hline & High School Students $N=629$ & University Students N=295 & P value \\
\hline Youth clinic & $244(39.0)$ & $105(35.8)$ & \\
\hline School/university & $127(20.3)$ & $24(8.2)$ & \\
\hline Other location & $26(4.2)$ & $12(4.1)$ & \\
\hline No preference & $186(29.7)$ & $138(47.1)$ & \\
\hline Preferred company for meeting the Youth Clinic team & & & $<0.001$ \\
\hline Other company & $22(3.5)$ & $8(2.7)$ & \\
\hline \multicolumn{4}{|l|}{ Barriers to use the services of a Youth Clinic } \\
\hline Financial difficulties & $107(17.0)$ & $60(20.3)$ & 0.220 \\
\hline Accessibility problems & $142(22.6)$ & $49(16.6)$ & 0.037 \\
\hline Worry about privacy and confidentiality & $173(27.5)$ & $89(30.2)$ & 0.402 \\
\hline Feelings of embarrassment and annoyance & $282(44.8)$ & $58(19.7)$ & $<0.001$ \\
\hline Clinic hours & - & $86(29.2)$ & $<0.001$ \\
\hline
\end{tabular}

barriers to using the services of the clinic for school students were the 'feelings of embarrassment and annoyance' and the 'worry about privacy and confidentiality'. As for university students, the major barriers were the 'worry about privacy and confidentiality' and the 'clinic hours'.

The major topics emerging from the qualitative studies were the lack of health related services and activities for the youth and the urgent need for social and psychological support and counseling. They appreciated an Internet website for youth and the possibility of getting in contact with professionals through it. They were interested in having the Youth Clinic reaching to the community. The top topics of interest were relationships parents-youth, sexual education, drugs, smoking, and diet and nutrition. The mostly discussed barrier to using the services of the clinic was the cost of the services.

This study has a number of strengths. First, it used both quantitative and qualitative methods, which allowed an in depth understanding of the issues. Second, it targeted students of both schools and universities in the different neighborhoods of the youth clinic, which has broadened the scope of this work. Third, it targeted participants other than students (i.e., parents, educators, and NGOs) allowing a representation of a wide spectrum of stakeholders. An additional strength is the high response rate to the survey studies. One limitation of the study is that the survey questionnaire instrument has not been used or validated in other settings. Another limitation is the lack of data validation with the study participants.

The results suggest the need for youth clinics to focus on the services most needed and desired, using the most preferred means of offering services, and taking into consideration the reported barriers. A youth clinic should also consider the services that are not as desired by the youth in spite of their importance from the public health point of view (e.g., drug, tobacco and alcohol use). An appropriate communication with the youth about the importance of these services may increase interest and demand.

The results suggest also a difference in opinion on some issues between parents, educators, and NGOs representatives on one side, and students on the other side. For instance, social and psychological counseling were the most requested services by parents, educators, and NGOs representatives but were of low interest for both school and university students. Such variation may be explained by the generational differences, and also by the fact that seeking psychological assistance is still considered a taboo in Lebanon. The students may also misunderstand the role of the social workers as limited to offering financial assistance. In another example, parents were extremely interested in the topic of the relation- 
Table 4. Comparison of High School Students and University Students for their Attitudes Toward Receiving Youth Health Information

\begin{tabular}{|c|c|c|c|}
\hline & High School Students $N=629$ & University Students N=295 & P Value \\
\hline Would like to receive youth health information & & & 0.099 \\
\hline No & $137(21.9)$ & $79(27.1)$ & \\
\hline Yes, in paper format & $193(30.9)$ & $73(25.0)$ & \\
\hline Preferred language for receiving health information & & & $<0.001$ \\
\hline Arabic & $293(46.9)$ & $66(22.8)$ & \\
\hline French & $200(32.0)$ & $164(56.6)^{*}$ & \\
\hline English & $132(21.1)$ & $60(20.7)$ & \\
\hline
\end{tabular}

* French is the academic language of $63.3 \%$ of the total number of university students participating in the study.

\section{Box III}

1- Involving a group of youth from the neighborhoods; this could have a direct impact on the youth and through them an indirect impact on the community.

2- Establishing a committee of parents within the Youth Clinic with members from the parents committee of each of the schools located in the clinic neighborhoods. This committee could act as the link between the neighborhoods' schools and the Youth Clinic.

3- $\quad$ Participating in community events and activities such as festivals and fairs.

4- Launching health related activities within the schools such as anti-smoking campaigns, health topics discussions, and contest between schools such as "best health topic poster".

5- $\quad$ Partnering with the different academic institutions in the neighborhoods.

6- Collaborating with grassroots organizations and NGOs in the neighborhoods with the dual goal of keeping the community informed about all the activities that is taking place, and also establishing a 'referral network' for young people.

ship parents-youth while students were not. While parents were interested in the hotline and the email communications with specialists, students were not.

Finally, the parents reported the location and the religious affiliation of the institution running the Youth Clinic as important barriers in our post-conflict and inter-religious settings. However, health services can also serve as an important reconciliation tool and be a key factor to rebuild postconflict communities [25].

\section{CONCLUSION}

This study has important implications for practice and research. Youth clinics need to explore the specific needs, expectations, and perceived barriers of their clients, i.e., the students but also the community. Privacy and confidentiality, being major concerns for the youth, need to be prioritized. Future research should study the effectiveness of interventions to increase the use of the youth clinics by the youth and how to optimize their effects on the health of their clients.

\section{LIST OF ABBREVIATIONS}

CUSFC $=\quad$ Centre Universitaire de Santé Familiale et Communautaire (University Center for Family and Community Health) $\begin{array}{ll}\text { UNFPA }= & \text { United Nations Population Fund } \\ \text { NGOs }= & \text { Non-Governmental Organizations }\end{array}$

\section{CONFLICT OF INTEREST}

The authors confirm that this article content has no conflicts of interest.

\section{ACKNOWLEDGEMENTS}

The United Nations Population Fund (UNFPA) office of Beirut-Lebanon funded this study.

Authors contributions: conception and design: Nancy Maroun, Hyam Kahi, Elie Akl, Nathalie Chemaly, Hala ElKahi; acquisition of data: Nathalie Chemaly, Nancy Maroun, Hyam Kahi; analysis and interpretation of data: Nancy Maroun, Elie Akl; drafting of manuscript: Nancy Maroun, Elie Akl; critical revision of the manuscript for important intellectual content: Nancy Maroun, Hyam Kahi, Elie Akl, Nathalie Chemaly, Hala ElKahi; obtaining of funding: Hyam Kahi.

\section{APPENDIX}

Survey questionnaire (French version) 


\section{Questionnaire}

\begin{tabular}{l|}
\hline Université \\
Spécialisation
\end{tabular}

Le Centre Universitaire de Santé Familiale et Communautaire, Campus des Sciences Médicales de L'USJ, a créé une clinique spéciale pour les jeunes (lieu d'écoute, de conseils et d'informations en matière de santé, dépassant le cadre rigide de la consultation médicale). Ci-joint un questionnaire qui sert à identifier les attentes des jeunes concernant les services à leur offrir, et les moyens dont ces services seront offerts.

1. Age

2. Sexe

Masculin Féminin

3. Comment évalues-tu le statut socio-économique de ta famille ? $\square$ Bas

$\square$ Moyen inférieur

$\square$ Moyen supérieur Élevé

4. As-tu consulté un médecin, au moins une fois, au cours des 12 derniers mois ?

$\square$ Non

$\square$ Oui, pour quelles raisons ? Tu peux cocher plusieurs réponses.
$\square$ Maladies aiguës (rhume, grippe, diarrhée, vomissements...)
$\square$ Maladies chroniques (diabète, asthme...)
$\square$ Vaccinations
$\square$ Conseils et informations
$\square$ Autres, précisez

As-tu consulté un autre professionnel de la santé, au moins une fois, au cours des 12 derniers mois ?
5. Psychologue
$\square$ Non
$\square$ Oui
6. Diététicienne
$\square$ Non
$\square$ Oui
7. Assistante sociale
$\square$ Non
$\square$ Oui
8. Infirmière
$\square$ Non
$\square$ Oui

Quel est ton degré d'intérêt pour chacun des services suivants offert par une clinique spécialisée pour jeunes?

\begin{tabular}{|l|c|c|c|c|c|}
\cline { 2 - 5 } \multicolumn{1}{l|}{} & $\begin{array}{c}\text { Pas du tout } \\
\text { intéressé }\end{array}$ & $\begin{array}{c}\text { Pas } \\
\text { intéressé }\end{array}$ & Neutre & Intéressé & $\begin{array}{c}\text { Extrêmement } \\
\text { intéressé }\end{array}$ \\
\hline 9. Consultations médicales & $\square$ & $\square$ & $\square$ & $\square$ & $\square$ \\
\hline 10. Consultations diététiques & $\square$ & $\square$ & $\square$ & $\square$ & $\square$ \\
\hline 11. Aide et counseling psychologique & $\square$ & $\square$ & $\square$ & $\square$ & $\square$ \\
\hline 12. Aide sociale & $\square$ & $\square$ & $\square$ & $\square$ & $\square$ \\
\hline 13. Soins infirmiers & $\square$ & $\square$ & $\square$ & $\square$ & $\square$ \\
\hline 14. Site Internet spécial pour jeunes & $\square$ & $\square$ & $\square$ & $\square$ & $\square$ \\
\hline 15. Informations concernant la santé & $\square$ & $\square$ & $\square$ & $\square$ & $\square$ \\
\hline 16. Informations concernant la sexualité & $\square$ & $\square$ & $\square$ & $\square$ & $\square$ \\
\hline
\end{tabular}

Quel est ton degré d'intérêt pour chacun des moyens suivants pour aborder des thèmes de santé avec les jeunes ?

\begin{tabular}{|l|c|c|c|c|c|}
\cline { 2 - 5 } \multicolumn{1}{c|}{} & $\begin{array}{c}\text { Pas du tout } \\
\text { intéressé }\end{array}$ & $\begin{array}{c}\text { Pas } \\
\text { intéressé }\end{array}$ & Neutre & Intéressé & $\begin{array}{c}\text { Extrêmement } \\
\text { intéressé }\end{array}$ \\
\hline 17. Rencontres individuelles avec un spécialiste & $\square$ & $\square$ & $\square$ & $\square$ & $\square$ \\
\hline 18. Rencontres de groupes de jeunes avec un spécialiste & $\square$ & $\square$ & $\square$ & $\square$ & $\square$ \\
\hline $\begin{array}{l}\text { 19. Ecoutes téléphoniques anonymes (Hotline) avec un } \\
\text { spécialiste }\end{array}$ & $\square$ & $\square$ & $\square$ & $\square$ & $\square$ \\
\hline 20. Site internet concernant la santé des jeunes & $\square$ & $\square$ & $\square$ & $\square$ & $\square$ \\
\hline 21. Communication par email avec un spécialiste & $\square$ & $\square$ & $\square$ & $\square$ & $\square$ \\
\hline
\end{tabular}


Questionnaire

Quel est ton degré d'intérêt pour chacun des sujets suivants concernant la santé des jeunes ?

\begin{tabular}{|l|c|c|c|c|c|}
\cline { 2 - 6 } \multicolumn{1}{c|}{} & $\begin{array}{c}\text { Pas du tout } \\
\text { intéressé }\end{array}$ & $\begin{array}{c}\text { Pas } \\
\text { intéressé }\end{array}$ & Neutre & Intéressé & $\begin{array}{c}\text { Extrêmement } \\
\text { intéressé }\end{array}$ \\
\hline 22. Alimentation et poids & $\square$ & $\square$ & $\square$ & $\square$ & $\square$ \\
\hline 23. Corps et ses changements & $\square$ & $\square$ & $\square$ & $\square$ & $\square$ \\
\hline 24. Sexualité et mesures de sécurité & $\square$ & $\square$ & $\square$ & $\square$ & $\square$ \\
\hline 25. Drogue, tabac, consommation d'alcool & $\square$ & $\square$ & $\square$ & $\square$ & $\square$ \\
\hline $\begin{array}{l}\text { 26. Problèmes de sommeil, maux de tête, fatigue et } \\
\text { stress }\end{array}$ & $\square$ & $\square$ & $\square$ & $\square$ & $\square$ \\
\hline $\begin{array}{l}\text { 27. Difficultés avec parents, difficultés à se faire des } \\
\text { amis }\end{array}$ & $\square$ & $\square$ & $\square$ & $\square$ & $\square$ \\
\hline
\end{tabular}

28. Où est-ce que tu préfères rencontrer l'équipe de la clinique des jeunes ? Cochez une seule réponse.

$\square$ 1. Dans la clinique des jeunes

$\square$ 2. Dans ton école

$\square$ 3. Dans le quartier où tu habites

$\square$ 4. Autre location, précisez

$\square$ 5. Pas de préférence

29. Avec qui tu préfères rencontrer l'équipe de la clinique des jeunes ? Cochez une seule réponse.

$\square$ 1. Avec tes parents

$\square$ 2. Avec tes amis

$\square$ 3. Seul(e)

$\square$ 4. Autre, précisez

30. Quelles sont les barrières qui peuvent t’empêcher de consulter une clinique spécialisée pour jeunes ? Tu peux cocher plusieurs réponses.

$\square$ 1. Difficultés de paiement

$\square$ 2. Problèmes d'accessibilité

$\square$ 3. Peur de la non protection de l'intimité et respet des secrets

$\square$ 4. Sentiment d'embarras, de gêne

$\square$ 5. Horaire d'ouverture du centre

$\square$ 6. Autres, précisez

31. Sais-tu qu’il existe une clinique spéciale pour jeunes à l’Université Saint Joseph, Campus des Sciences Médicales (Toubbieh) ?
$\square$ Non
$\square$ Oui

32. Aimerais-tu recevoir du centre de santé de l’USJ des informations sur la santé des jeunes? Cochez une seule réponse.
$\square$ Non
$\square$ Oui, sur papier
Oui, par email ou internet

33. Quelle est ta langue préférée pour lire des informations sur la santé?
$\square$ Arabe
$\square$ Français
$\square$ Anglais

34. Serais-tu intéressé à bénéficier de la clinique spécialisée pour jeunes à l’Université Saint Joseph?

$\square$ Non, pourquoi ?

$\square$ Oui, pourquoi ? 


\section{REFERENCES}

[1] Irwin CE, Burg SJ, Cart CU. America's adolescents: Where have we been, where are we going? J Adolesc Health 2002; 31(6 suppl): 91-121.

[2] Safe Passages through Adolescence: Communities Protecting the Health and Hopes of Youth. Lessons Learned from W. K. Kellogg Foundation Programming: Kellogg Foundation, Battle Creek, MI 1998.

[3] Wauquiez L. La santé et la protection sociale des étudiants. Rapport d'information $n^{\circ}$ 3494. Paris: Assemblée nationale 2006.

[4] Roberts RE, Chen Y-W, Solovitz BL. Symptoms of DSM-III-R major depression among Anglo, African and Mexican American adolescents. J Affect Disord 1995; 36(1-2): 1-9.

[5] Guilbert P, Gautier A, Baudier F, Trugeon A, Eds. Baromètre santé 2000: Les comportements des 12-25 ans. Synthèse des résultats nationaux et régionaux. Saint-Denis Cedex: Institut national de prévention et d'éducation pour la santé 2004.

[6] Coiro M, Zill N, Bloom B. Health of our nation's children. Vital Health Stat 1994; 10(191): 1-61.

[7] Pommier J, Deschamps J, Romero M, et al. Attitudes regarding the delivery of formal and informal care: comparison of French and Chilean adolescents. Santé Publique 2002; 14(4): 371-87.

[8] Zimmer-Gembeck M, Alexander T, Nystrom R. Adolescents report their need for and use of health care services. J Adolesc Health 1997; 21: 388-99.

[9] Booth M, Bernard D, Quine S, Kang M, Usherwood T, Alperstein G. Access to health care among australian adolescents young people's perspectives and their sociodemographic distribution. J Adolesc Health 2004; 34: 97-103.

[10] Elliott B, Larson J. Adolescents in mid-sized and rural communities: Foregone care, perceived barriers, and risk factors. J Adolesc Health 2004; 35: 303-9.

[11] Klein JD, Wilson KM, McNulty M, Kapphahn C, Scott CK. Access to medical care for adolescents: results from the 1997 Commonwealth Fund Survey of the Health of Adolescent Girls - Placing adolescents on the American national agenda for the 1990s. J Adolesc Health 1999; 25(2): 120-30.

[12] Milne AC, Chesson R. Health services can be cool: partnership with adolescents in primary care. Family Pract 2000; 17(4): 305-8.

[13] Pommier J, Mouchtouris A, Billot L. Self-reported determinants of health service use by French adolescents. Int J Adolesc Med Health (IJAMH) 2001; 13: 115-29.
[14] Gould M, Munfakh J, Lubell K, Kleinman M, Parker S. Seeking help from the internet during adolescence. J Am Acad Child Adolesc Psychiatry 2002; 41(10): 1182-9.

[15] Afifi EKF, Soweid R, Taljeh C, Kanj M, Shediac-Rizkallah M. High school students in postwar Lebanon: Attitudes, information sources, and perceived needs related to sexual and reproductive health. J Adolesc Health 2001; 29: 153-5.

[16] Jerjes A. Survey of knowledge, attitudes, beliefs, and practices of secondary school students in relation to HIV/AIDS: Report to the National AIDS Program1994.

[17] Sibai A, Kanaan N. Youth health risk behaviour survey among secondary students in Lebanon: Prevalence and clustering of risk behaviors. Beirut: WHO/UNICEF1999.

[18] IGSPS. Recueil national des statistiques sanitaires au Liban. Beirut: Institut de Gestion de la Santé et de la Protection Sociale (IGSPS), Université Saint Joseph http://www.igsps.usj.edu.lb/docs/recueil2004.pdf2004

[19] Soweid RA, Abou Jaoude S. Lebanon, 2005 Global school-based student health survey (GSHS). Beirut: Centers for Disease Control and Prevention (CDC), World Health Organization (WHO), Ministry of Education and Higher Education, Ministry of Public Health 2007.

[20] Goodburn E, Ross D. A Picture of Health? a review and annotated bibliography of the health of young people in developing countries. Geneva: World Health Organization (WHO/FHE/ADH/95.14) 1995.

[21] El Kahi H. Le comportement de demande de soins des jeunes universitaires Libanais. Beirut: Saint Joseph University of Beirut 2008.

[22] Green J, Thorogood N. Qualitative Methods for Health Research. London; thousand Oaks, Calif.: Sage Publications 2004.

[23] Mayer R, Ouellet F. Méthodologie de la recherche pour intervenants sociaux. Boucherville: Gaëtan Morin éditeur 1991.

[24] Creswell J. Qualitative Inquiry and research design: Choosing among the five traditions. Thousand Oaks, CA: Sage Publications 1998.

[25] Maroun N. Community health projects to reconcile and rebuild post-conflict communities: A Lebanese case. American Public Health Association (APHA) 135th Annual Meeting and Expo; Nov; Washington, DC, USA 2007.

(C) Maroun et al.; Licensee Bentham Open.

This is an open access article licensed under the terms of the Creative Commons Attribution Non-Commercial License (http://creativecommons.org/licenses/ by-nc/3.0/) which permits unrestricted, non-commercial use, distribution and reproduction in any medium, provided the work is properly cited. 